\title{
Conducting Polymer Based Nucleic Acid Sensor for Environment Monitoring
}

\author{
Bansi Dhar MALHOTRA ${ }^{\dagger a}$, Nirmal PRABHAKAR ${ }^{\dagger}$, and Pratima R. SOLANKI ${ }^{\dagger}$, Nonmembers $^{\circ}$
}

\begin{abstract}
SUMMARY Nucleic acid sensor based on polyaniline has been fabricated by covalently immobilizing double stranded calf thymus (dsCT) DNA onto perchlorate $\left(\mathrm{ClO}_{4}^{-}\right)$doped polyaniline (PANI) film deposited onto indium-tin-oxide (ITO) glass plate using 1-(3-(dimethylamino) propyl)3-ethylcarbodiimide hydrochloride (EDC)/ $N$-hydroxyl succinimide (NHS) chemistry. These dsCT-DNA-PANI/ITO and PANI/ITO electrodes have been characterized using square wave voltammetry, electrochemical impedance, and Fourier-transform-infra-red (FTIR) measurements. This disposable dsCT-DNA-PANI/ITO bioelectrode is stable for about four months, can be used to detect arsenic trioxide $(0.1 \mathrm{ppm})$ in $30 \mathrm{~s}$.

key words: nucleic acid sensor, electrochemical, polyaniline, perchlorate, arsenic trioxide
\end{abstract}

\section{Introduction}

Increased use of heavy metals like arsenic, cadmium, copper, lead and mercury in industrial waste has lead to the release of toxicants in environment. Among these, World Health Organisation (WHO) has recommended arsenic as a serious toxicant in drinking water. The systemic and chronic exposure to arsenic leads to serious disorders such as vascular diseases including hypertension, irritation of skin and mucus membrane as well as determatitis and injection of inorganic arsenic increases the risk of developing cancer of bladder, liver, kidney and skin [1]. Arsenic is found in form of arsenite $\left(\mathrm{As}^{3+}\right)$ and arsenate $\left(\mathrm{As}^{5+}\right)$, and can participate in metabolism with reduction and/or methylation in many tissues [2]. Mouron et al. evaluated the degree of damage induced by cadmium and arsenic salts in a human cell line using comet assay [3]. The classical methods for the analysis of metals (cadmium, copper, iron) such as atomic absorption spectroscopy, ion chromatography and mass spectrometric techniques need to be carried out in laboratory after sampling [4]. These techniques require expensive reagents, manpower and are time-consuming. To overcome these problems biosensor is one of the devices that is portable, cost-effective and provides quick response. Biosensors have the ability to monitor presence of genotoxicants in aqueous samples.

DNA biosensors have recently become powerful tools to provide information on insecticides, pesticides and toxic compounds in environmental samples. Electrochemical

\footnotetext{
Manuscript received June 9, 2008.

Manuscript revised August 20, 2008.

${ }^{\dagger}$ The authors are with Biomolecular Electronics and Conducting Polymer Reseach Group, National Physical Laboratory, New Delhi, India.

a) E-mail: bansi.malhotra@gmail.com

DOI: 10.1093/ietele/e91-c.12.1889
}

DNA biosensors have been fabricated using various matrices such as graphite, carbon electrode, self-assembled monolayers and conducting polymers for detection of genotoxicants [5]-[8]. The disposable graphite electrode with electrochemically adsorbed dsCT-DNA has been employed for detection of toxic aromatic amines; 2-naphthylamine $(0-20 \mu \mathrm{M})$, 2-anthramine $(0-0.80 \mu \mathrm{M}, 1,2$, diamino anthraquinone $(0-0.20 \mu \mathrm{M})$ and acridine orange $(0-0.20 \mu \mathrm{M})$, respectively [7]. Lucarelli et al. (2002) have developed an electrochemical biosensor based on screen-printed carbon electrode for monitoring of toxicants/pollutants like bisphenol (1.0-5.0 $\mu \mathrm{g} / \mathrm{mL}), o$-chlorophenol (OCP) and 2aminoanthracene (2-AA) $(0.08-20 \mu \mathrm{g} / \mathrm{mL})$ using square wave voltammetry technique [9]. DNA immobilized glassy carbon electrodes have been used to investigate the interaction of benznidazole with DNA molecule [10].

Conducting polymer matrices have been the subject of great interest for researchers due to various properties of mechanical flexibility, high surface area, chemical specificities, tunable conductivities and easy processibility that can be used to fabricate biosensors. The double stranded calf thymus DNA physisorbed onto polypyrrole (PPy)-polyvinyl sulfonate (PVS) film has been used to detect 2-aminoanthracene (2-AA, 0.01-20 ppm) and $o$ chlorophenol (OCP, 0.1-30 ppm) using cyclic voltammetry [5]. The electrochemical entrapment of double-stranded calf thymus DNA onto polypyrrole-polyvinylsulphonate film has been reported for detection of chlorpyrifos (0.0016$0.025 \mathrm{ppm})$, malathion $(0.17-5.0 \mathrm{ppm}), 2$-aminoanthracene (0.001-6.0 ppm) and 3-chlorophenol (0.01-55.0 ppm), respectively [6]. Polyaniline (PANI) due to its excellent conductivity, long-term environmental stability, signal amplification and elimination of electrode fouling is considered suitable for fabrication of novel biosensors [11]-[15]. Moreover, polyaniline is ideally suited for covalent binding of biomolecules (enzymes and DNA) due to the presence of active functional groups.

In the present manuscript, we report results of the studies relating to the immobilization and characterization of dsCT-DNA covalently immobilized onto perchlorate doped polyaniline film deposited onto indium-tin-oxide (ITO) glass plate using EDC/NHS chemistry for detection of arsenic trioxide. 


\section{Experiment}

\subsection{Chemicals and Reagents}

Aniline (An), N-hydroxysuccinimide (NHS), N-(3-dimethylaminopropyl)-N-ethyl-carbodiimide hydrochloride (EDC), tris-base, ethylene diamine tetraacetic acid (EDTA), potassium monohydrogen and potassium dihydrogen phosphate were procured from Sigma, USA. The double stranded calf thymus DNA (dsCT-DNA) was obtained from Genei, Bangalore Pvt. Ltd. Arsenic trioxide and lithium perchlorate $\left(\mathrm{LiClO}_{4}\right)$ were purchased from Loba Chemie, India. Indium-tin-oxide (ITO) coated glass plates were obtained from the Balzers, UK. All chemicals used were of molecular biology (MB) grade. The deionized water (Milli Q 10 TS) was used for the preparation of reagents. All solutions and glasswares were autoclaved prior to being used.

\subsection{Preparation of dsCT-DNA Immobilized PANI Elec- trode}

Electrochemically polyaniline (PANI)-perchlorate $\left(\mathrm{ClO}_{4}^{-}\right)$ films were prepared chronopotentiometrically using a Potentiostat-Galvanostat (Princeton Applied Research, Model No. $273 \mathrm{~A})$. Monomer solution containing aniline $(0.1 \mathrm{M})$ and $\mathrm{LiClO}_{4}(0.1 \mathrm{M})$ was electropolymerized at $0.0015 \mathrm{~A}$ for about $500 \mathrm{~s}$ using a three-electrode cell consisting of $\mathrm{Ag} / \mathrm{AgCl}$ as reference, platinum $(\mathrm{Pt})$ as counter electrode and ITO as a working electrode $\left(0.25 \mathrm{~cm}^{2}\right)$. The dsCT-DNA has been covalently immobilized onto polyaniline films using EDC/NHS chemistry. EDC (100 mM) and NHS $(200 \mathrm{mM})$ were used for the activation of phosphate group of dsCT-DNA for binding with $\mathrm{NH}_{2}$ group of polyaniline. The solution containing DNA $\left(1 \mathrm{mg} \mathrm{mL}^{-1}\right)$, EDC and NHS was kept for about $12 \mathrm{~h}$ at room temperature. We have optimized the concentration of dsCT-DNA utilized for covalent immobilization onto PANI/ITO bioelectrode and have found that $10 \mu \mathrm{L}$ dsCT-DNA ( $1 \mathrm{mg} / \mathrm{mL})$ is sufficient to cover the electrode surface (data not shown) [5], [16]. The activated dsCT-DNA $(10 \mu \mathrm{L})$ of solution dispensed onto PANI/ITO electrode was kept for $2 \mathrm{~h}$ in a humid chamber whereafter it was stored in a refrigerator for about $8 \mathrm{~h}$. These dsCT-DNA-PANI/ITO bioelectrodes were rinsed with autoclaved deionized water to remove any unbound dsCT-DNA from the surface and were stored at $4^{\circ} \mathrm{C}$ when not in use.

\subsection{Characterization of dsCT-DNA-PANI/ITO Bioelec- trode}

PANI/ITO electrodes and dsCT-DNA-PANI/ITO bioelectrodes have been characterized using square wave voltammetry (SWV) technique, electrochemical impedance measurements (Autolab Potentiostat/Galvanostat from Eco Chemie (Netherlands) using a three-electrode system in phosphate buffer saline (PBS) solution $(50 \mathrm{mM}, \mathrm{pH} 7.0$,
$0.9 \% \mathrm{NaCl})$ containing $5 \mathrm{mM}\left[\mathrm{Fe}(\mathrm{CN})_{6}\right]^{3-/ 4-}$ and Fouriertransform-infrared (Perkin Elmer BX), respectively.

These dsCT-DNA-PANI/ITO bioelectrodes have been used to investigate the interaction of arsenic trioxide with dsCT-DNA using square wave voltammetry in phosphate buffer $\left(50 \mathrm{mM}\right.$, pH 7.0) containing $5 \mathrm{mM}\left[\mathrm{Fe}(\mathrm{CN})_{6}\right]^{3-/ 4-}$. It has been found that $30 \mathrm{~s}$ are sufficient for obtaining maximum reduction in the guanine oxidation current. A control experiment performed using PANI/ITO film to investigate the effect of arsenic trioxide (10 ppm) onto the PANI/ITO film does not reveal any change in the oxidation current. The shelf-life of the dsCT-DNA-PANI/ITO bioelectrode investigated under desiccated conditions as a function of time has been found to be about four months under refrigerated conditions. UV-Visible spectroscopy (Shimadzu, 160 A) and FT-IR studies have been performed to investigate the mechanism of interaction of dsCT-DNA with arsenic trioxide.

\section{Results \& Discussion}

\subsection{Square Wave Voltammetric Studies}

Figure 1 shows the square wave voltammograms obtained for PANI/ITO film and dsCT-DNA-PANI/ITO bioelectrode in the range of 0.2 to $1.2 \mathrm{~V}$ in phosphate buffer $(50 \mathrm{mM}, \mathrm{pH}$ 7.0) containing $5 \mathrm{mM}\left[\mathrm{Fe}(\mathrm{CN})_{6}\right]^{3-/ 4-}$ (as an electron mediator). The oxidation peaks can be seen at about $0.39 \mathrm{~V}$ for the PANI/ITO bioelectrode describing oxidation of aniline to radical cation. The dsCT-DNA-PANI/ITO bioelectrode shows guanine oxidation peak at about $0.5 \mathrm{~V}$ which can be attributed to the dsCT-DNA molecules immobilized at the PANI/ITO surface. The guanine oxidation peak (Fig. 1) may arise from lone pair of electrons of DNA on application of potential.

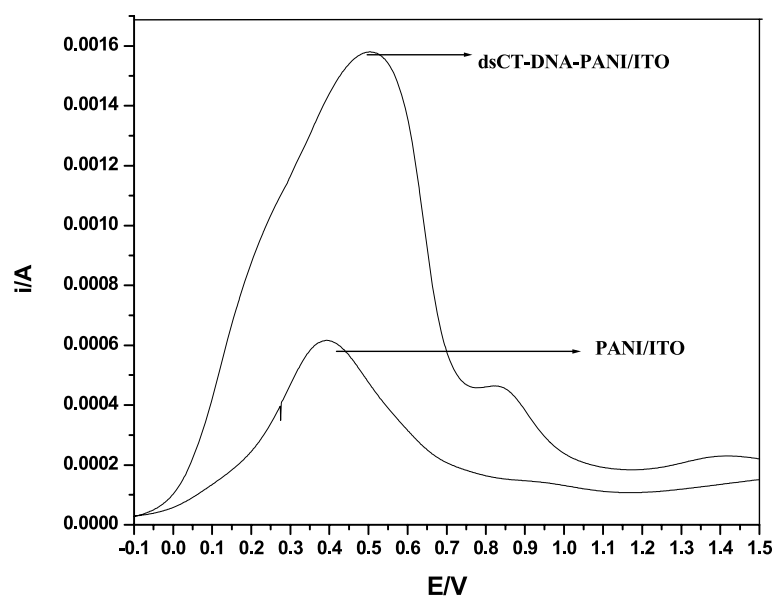

Fig. 1 Square wave voltammograms for PANI/ITO film and dsCT-DNAPANI/ITO bioelectrode in phosphate buffer $(50 \mathrm{mM}, \mathrm{pH} 7.0)$ containing $5 \mathrm{mM}\left[\mathrm{Fe}(\mathrm{CN})_{6}\right]^{3-/ 4-}$ at $0.07005 \mathrm{~V}$ amplitude between 0.2 to $1.2 \mathrm{~V}$ potential and $0.0015 \mathrm{~V}$ step potential. 


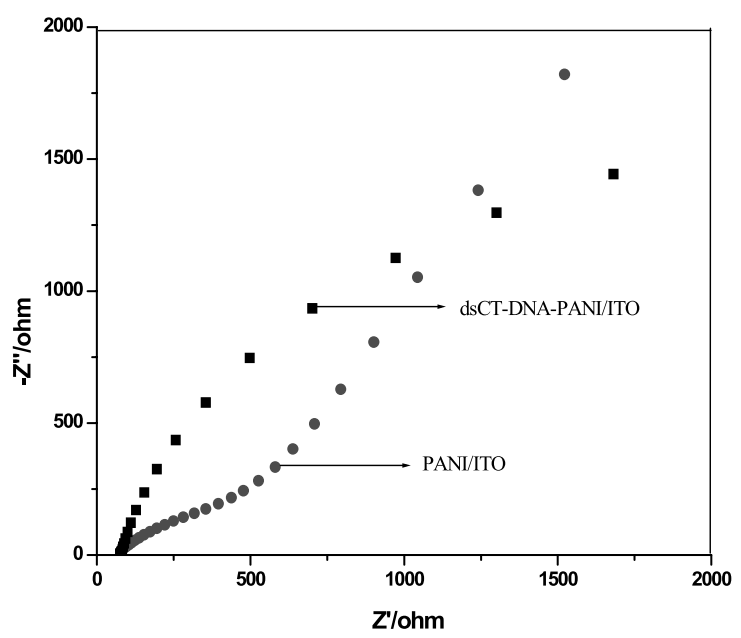

Fig. 2 Impedance spectra of PANI/ITO film and dsCT-DNA-PANI/ITO bioelectrode in phosphate buffer $(50 \mathrm{mM}, \mathrm{pH} 7.0,0.9 \% \mathrm{NaCl})$ containing $5 \mathrm{mM}\left[\mathrm{FeCN}_{6}\right]^{3-/ 4-}$.

\subsection{Electrochemical Impedance Spectroscopy}

Figure 2 shows the Nyquist plots of PANI/ITO electrode and dsCT-DNA-PANI/ITO bioelectrode in the frequency range of $0.01-10^{5} \mathrm{~Hz}$. In the Nyquist plot of impedance spectra, the semicircle portion at higher frequencies corresponding to the electron-transfer limited process and the linear portion seen at lower frequencies may be ascribed to diffusion. The value of the electron transfer resistance (semicircle diameter) $\left(\mathrm{R}_{\mathrm{CT}}\right)$ depends on dielectric and insulating features at the electrode/electrolyte interface. The $\mathrm{R}_{\mathrm{CT}}$ values obtained for PANI/ITO film and dsCT-DNAPANI/ITO electrode have been obtained as $2.38 \times 10^{3} \Omega$ and $6.60 \times 10^{3} \mathrm{~V} \Omega$, respectively. The increased $R_{C T}$ value in the case of dsCT-DNA-PANI/ITO bioelectrode contributes to increased negative charge density onto the electrode because phosphate backbone of dsCT-DNA results in higher resistance to the flow of electrons between the electrode and $\left[\mathrm{Fe}(\mathrm{CN})_{6}\right]^{3-/ 4-}$ solution, indicating the binding of dsCTDNA onto PANI/ITO surface [17].

\subsection{Fourier Transform Infra-Red Spectroscopy (FTIR) Studies}

Figure 3 shows FT-IR spectra of PANI/ITO electrode and dsCT-DNA-PANI/ITO bioelectrode. The $1545 \mathrm{~cm}^{-1}$ peak can be ascribed to $\mathrm{N}-\mathrm{H}$ bending. The 1735, 1679 and $1469 \mathrm{~cm}^{-1}$ peaks are assigned to the nitrogenous bases of DNA molecule. Peak at $1232 \mathrm{~cm}^{-1}$ is due the presence of phosphate backbone of DNA molecule.

The absorption bands at 1110 and $1055 \mathrm{~cm}^{-1}$ observed for polyaniline merge resulting in a sharp band at $1071 \mathrm{~cm}^{-1}$ arise due to the formation of coordinate bond between nitrogen of amine group in PANI and dsCT-DNA. The absorption band at $790 \mathrm{~cm}^{-1}$ ascribed to the P-N bond formed between the phosphate group of DNA and nitrogen moiety

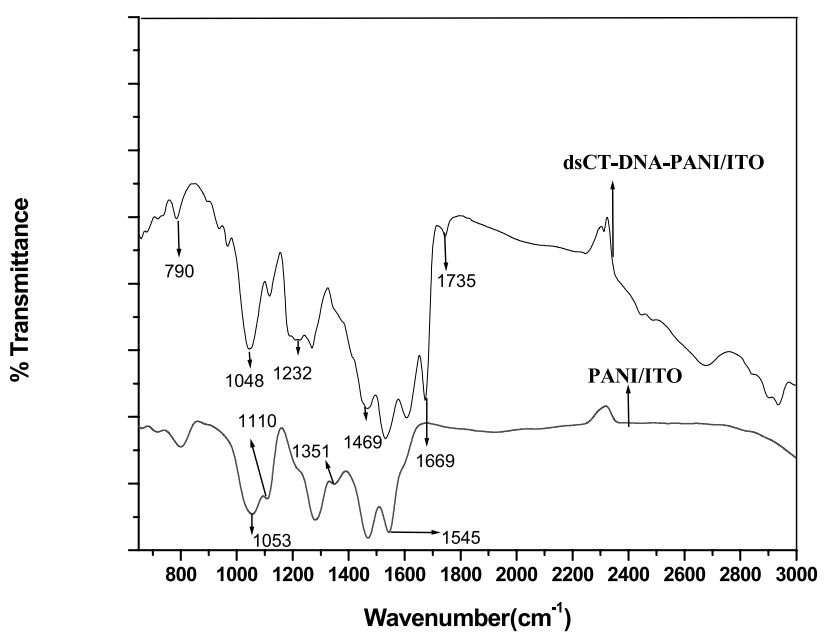

Fig. 3 FTIR spectra of PANI/ITO film and dsCT-DNA-PANI/ITO bioelectrodes.

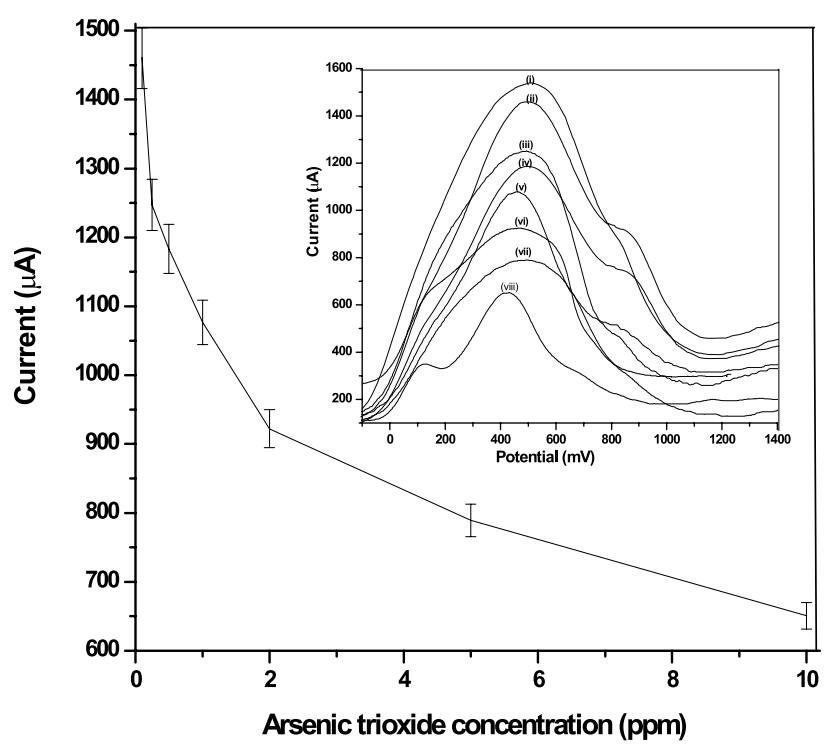

Fig. 4 Variation of current obtained for dsCT-DNA-PANI/ITO bioelectrode as a function of arsenic trioxide concentration $(0.1-10 \mathrm{ppm})$. Inset shows the square wave voltammograms in phosphate buffer $(50 \mathrm{mM}$, $\mathrm{pH}$ 7.0) containing $5 \mathrm{mM}\left[\mathrm{Fe}(\mathrm{CN})_{6}\right]^{3-/ 4-}$ for arsenic trioxide concentration (i) $0.0 \mathrm{ppm}$ (ii) $0.1 \mathrm{ppm}$, (iii) $0.25 \mathrm{ppm}$, (iv) $0.5 \mathrm{ppm}$, (v) $1.0 \mathrm{ppm}$, (vi) $2.0 \mathrm{ppm}$, (vii) $5.0 \mathrm{ppm}$, (viii) $10.0 \mathrm{ppm}$ in phosphate buffer (50 mM, pH 7.0) containing $5 \mathrm{mM}\left[\mathrm{Fe}(\mathrm{CN})_{6}\right]^{3-/ 4-}$ at $0.07005 \mathrm{~V}$ amplitude between 0.2 to $1.2 \mathrm{~V}$ potential and $0.0015 \mathrm{~V}$ step potential.

of polyaniline chain indicates covalent immobilization DNA with polyaniline via EDC/NHS coupling [18].

\subsection{Response Studies of dsCT-DNA-PANI/ITO Bioelec- trode}

Figure 4 exhibits the variation of current obtained for dsCTDNA-PANI/ITO bioelectrode as a function of arsenic trioxide concentration. The inset exhibits the square wave voltammograms (SWVs) of the in phosphate buffer $(50 \mathrm{mM}$, $\mathrm{pH}$ 7.0) containing $5 \mathrm{mM}\left[\mathrm{Fe}(\mathrm{CN})_{6}\right]^{3-/ 4-}$ as a function of ar- 


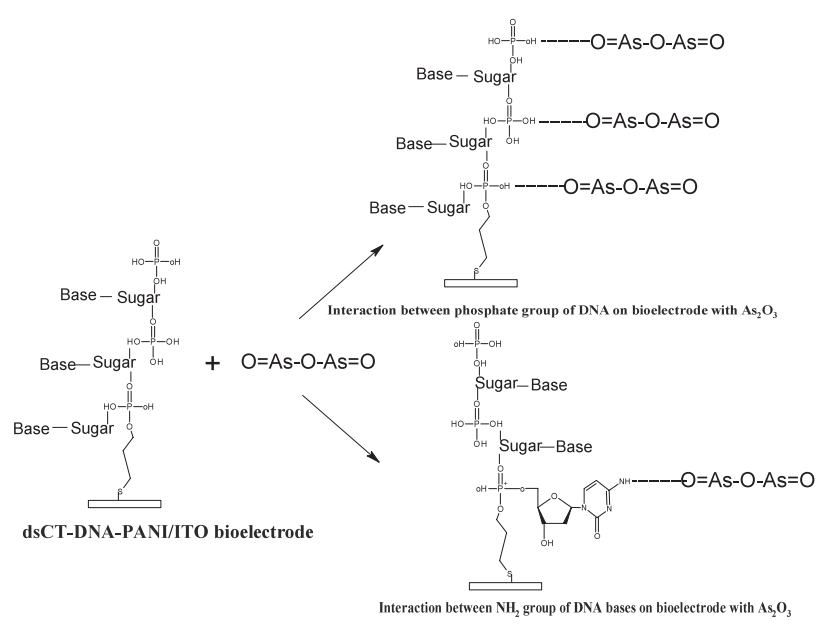

Scheme 1 Interaction between the dsCT-MCE-Au bioelectrode with arsenic trioxide.

senic trioxide concentration in the range $0.0-10.0 \mathrm{ppm}$. It can be seen that the guanine oxidation current decreases as the arsenic trioxide concentration increases. No further decrease in the guanine oxidation current of dsCT-DNAPANI/ITO bioelectrode occurs at arsenic trioxide concentration $\geq 10.0 \mathrm{ppm}$ and concentration $\leq 0.1 \mathrm{ppm}$ revealing low detection limit. The reduction in the current value can be related to steric hindrance arising due to the interaction of DNA moiety with arsenic trioxide molecules.

The observed decrease in the guanine oxidation current reveals the interaction of $\mathrm{As}_{2} \mathrm{O}_{3}$ with the DNA molecules. There are two possibilities for interaction of arsenic trioxide with dsCT-DNA. Firstly, the electrostatic interaction may occur between $\mathrm{As}_{2} \mathrm{O}_{3}$ and negative charged sugar phosphate backbone. Secondly, the interaction may arise between the $\mathrm{NH}_{2}$ group of nitrogeneous bases (guanine) and oxygen of $\mathrm{As}_{2} \mathrm{O}_{3}$ (Scheme 1).

The proposed reaction of the arsenic trioxide with the DNA molecule has been investigated using UV-visible spectroscopy and FT-IR measurements in solution phase.

\subsection{FTIR and UV-vis Spectroscopy Studies}

FTIR and UV-vis spectroscopic studies of blank DNA on addition of arsenic trioxide have been done in the tris buffer (10 mM)-EDTA (1 mM) at (pH 8.0), respectively.

Figure 5 shows results of the UV-visible studies carried out using DNA (curve i) and DNA + arsenic trioxide (curve ii). It is observed that after addition of arsenic trioxide ino the dsCT-DNA solution, the absorption increases with slight shift of the peak towards the positive side (bathochromic shift), resulting in interaction of arsenic trioxide with dsCTDNA molecule. There is also a possibility of interaction between the phosphate group of dsCT-DNA molecule and oxide group of arsenic trioxide (Scheme 1).

The results of FTIR studies (data not shown) obtained for blank dsCT-DNA and the dsCT-DNA+ arsenic trioxide in tris buffer [Tris $(10 \mathrm{mM})-$ EDTA $(1 \mathrm{mM})(\mathrm{pH} 8.0)]$ reveal

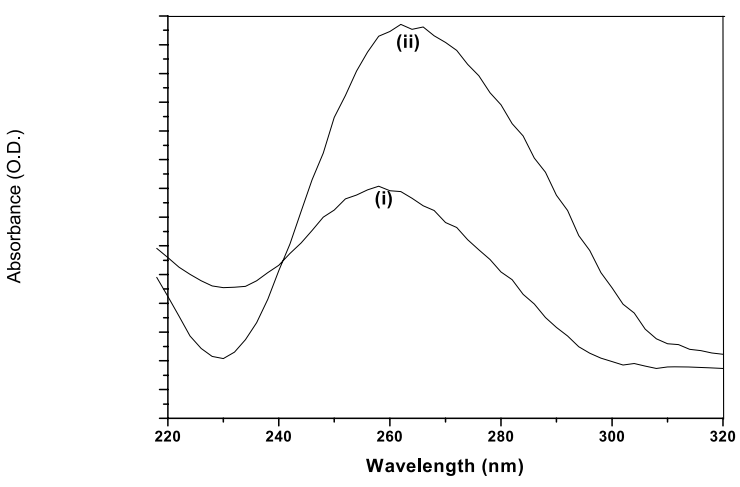

Fig. 5 UV-visible spectra of (i) dsCT-DNA, (ii) dsCT-DNA + arsenic trioxide and in Tris $(10 \mathrm{mM})$-EDTA $(1 \mathrm{mM})(\mathrm{pH} 8.0)$.

peaks at 1050, 1239, 1267, 1650, 1050, 2155, 2352 and $3101 \mathrm{~cm}^{-1}$. The peaks at 1650 and $3101 \mathrm{~cm}^{-1}$ are ascribed to the N-H stretching and bending, respectively. In the presence of arsenic trioxide, the magnitudes of DNA peaks at 1650 , and $3101 \mathrm{~cm}^{-1}$ decrease indicating interaction between arsenic trioxide and DNA moiety(data not shown).

\section{Conclusions}

The disposable dsCT-DNA-PANI/ITO electrode has been fabricated to detect arsenic trioxide $(0.1-10.0 \mathrm{ppm})$ within $30 \mathrm{~s}$. The mechanism of interaction of the arsenic trioxide with dsCT-DNA has been proposed. Efforts are being made to improve the detection limit and the stability beyond 4 months and to utilize these genoelectrodes for testing of real samples such as waste water and industrial waste. Attempts should be made to commercialize the disposable electrode using screen printing technique. And it should be interesting to utilize this polyaniline based nucleic acid sensor for estimation of other heavy metals, pesticides and insecticides etc.

\section{Acknowledgments}

We thank Dr. Vikram Kumar, Director, NPL, New Delhi, India for providing facilities. Financial support received under the DBT sponsored project Grant/DBT/CSH/GIA/0212/ 2007, DST sponsored Project DST/TDT/TSG/ME/2006/2 and India-Japan project DST/INT/JAPP-21/07 is gratefully acknowledged.

\section{References}

[1] C.O. Abernathy, Y.P. Liu, D. Longfellow, H.V. Aposhian, B. Beac, B. Fowler, R. Goyer, R. Menzer, T. Rossman, C. Thompson, and M. Waalkes, "Arsenic: Health effects, mechanism of actions and research issues," Environmental Health Perspectives, vol.107, pp.593597, 1999.

[2] M. Ozsoz, A. Erdem, P. Kara, K. Kerman, and D. Ozkan, "Electrochemical biosensor for the detection of interaction between arsenic trioxide and DNA based on guanine signal," Electroanalysis, vol.15, pp.613-619, 2003.

[3] S.A. Mouron, C.D. Golijow, and F.N. Dulout, "DNA damage by cadmium and arsenic salts assessed by the single cell gel electrophoresis 
assay," Mutation Research, vol.498, pp.47-55, 2001.

[4] J.Z. Wu and P.C. Ho, "Evaluation of the in vitro activity and in vivo bioavailability of realgar nanoparticles prepared by cryo-grinding," Euro. J. Pharma. Scien., vol.29, pp.35-44, 2006.

[5] K. Arora, A. Chaubey, R. Singhal, R.P. Singh, M.K. Pandey, S.B. Samanta, S. Chand, and B.D. Malhotra, "Application of electrochemically prepared polypyrrole - Polyvinyl sulphonate films to DNA biosensor," Biosens. Bioelectron., vol.21, pp.1777-1783, 2006.

[6] (a) N. Prabhakar, K. Arora, S.P. Singh, H. Singh, and B.D. Malhotra, "DNA entrapped polypyrrole - Polyvinyl sulfonate film for application to electrochemical biosensor," Anal. Biochem., vol.366, pp.71-79, 2007. (b) N. Prabhakar, K. Arora, S.P. Singh, M.K. Pandey, H. Singh, B.D. Malhotra, "Polypyrrole-polyvinyl sulphonate film based disposable nucleic acid biosensor," Anal Chim. Acta, vol.589, pp.6-13, 2007.

[7] G. Chitti, G. Marrazza, and M. Mascini, "Electrochemical DNA biosensor for environmental monitoring," Anal. Chim. Acta, vol.427, pp.155-164, 2001.

[8] J. Wang and F.J. Zhou, "Scanning electrochemical microscopic imaging of surface-confined DNA probes and their hybridization via guanine oxidation," Electroanal. Chem., vol.537, pp.95-102, 2002.

[9] F. Lucrelli, G. Palchetti, M. Marrazza, and M. Mascini, "Electrochemical DNA biosensor as a screening tool for the detection of toxicants in water and wastewater samples," Talanta, vol.56, pp.949_ 957, 2002.

[10] M.A. La-Scalea, S.H.P. Serrano, E.I. Ferreira, and B.A.M. Oliveria, "Voltammetric behaviour of benznidaxole at a DNA-electrochemical biosensor," J. Pharm. Biomed. Anal., vol.29, pp.561-568, 2002.

[11] A.N. Ivanov, G.A. Evtugyn, L.V. Lukachova, E.E. Karyakina, H.C. Budnikov, S.G. Kiseleva, A.V. Orlov, G.P. Kapacheva, and A.A. Karyakin, "New polyaniline based potentiometric biosensor for pesticide detection," J. IEEE Sens., vol.3, pp.333-340, 2008.

[12] R. Nagarajan, S. Tripathy, J. Kumar, F.F. Bruno, and L. Samuelson, "Enzymatic synthesis of electrically conducting molecular complex of polyaniline and poly (vinyl phosphonic acid)," Macromol., vol.33, pp.9542-9547, 2000

[13] W. Liu, J. Kumar, S. Tripathy, K.J. Senecal, and L.J. Samuelson, "Enzymatically synthesized conducting polyaniline," J. Am. Chem. Soc., vol.121, pp.71-78, 1999.

[14] S. Singh, P.R. Solanki, M.K. Pandey, and B.D. Malhotra, "Cholesterol biosensor based on cholesterol esterase, cholesterol oxidase and peroxidase immobilized onto conducting polyaniline films," Sens. Actuators B, vol.115, pp.534-541, 2006.

[15] B.D. Malhotra, A. Chaubey, and S.P. Singh, "Prospects of conducting polymers in biosensors," Anal. Chim. Acta, vol.578, pp.59-74, 2006.

[16] P.R. Solanki, N. Prabhakar, M.K. Pandey, and B.D. Malhotra, "Nucleic acid sensor for insecticide detection," J. Mol. Recognition., vol.21, pp.217-223, 2008.

[17] V. Dharuman, T. Grunald, E.A. Nebling, L. Blohm, and R. Hintsche, "Label-free impedance detection of oligonucleotide hybridization on interdigitated ultramicroelectrodes using electrochemical redox probes," Biosens. Bioelectron., vol.21, pp.645-654, 2005.

[18] G. Socrates, Infrared characteristics group frequencies, 2nd ed., Chapter 17, pp.177-187, John Wiley \& Sons, 1994.

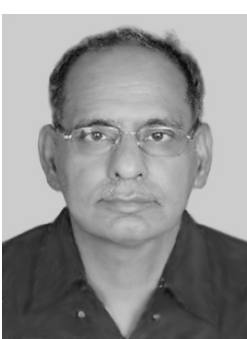

Bansi Dhar Malhotra received his Ph.D. in Physics from University of Delhi, Delhi, India in $1980 . \quad \mathrm{He}$ has research experience of about 25 years in the area of Biomolecular Electronics and has guided $12 \mathrm{Ph} . \mathrm{D}$. students till date. He has published 144 research papers in peer reviewed journals in the area of biosensors, nano-materials, conducting polymers, Langmuir-Blodgett films and self assembled monolayers. He is currently Scientist $\mathrm{G}$ and Head of the Biomolecular Electronics \& Conducting Polymer Research Group (BECPRG), National Physical Laboratory, New Delhi, India.

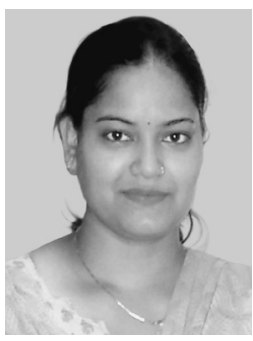

Nirmal Prabhakar recieved her M.Sc. in 2003 in Biochemistry from the School of Life Sciences, Dr. B.R.A. University, Agra. She is presently working on research and development of nucleic acid biosensors and is a Senior Research Fellow in Biomolecular Electronics and Conducting Polymer Research Group, National Physical Laboratory, New Delhi, India.

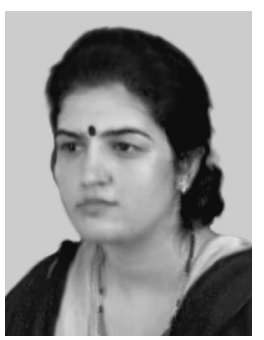

Pratima R. Solanki obtained her M.Sc. and Ph.D. degrees from Maharishi Dayanand University, Rohtak (Haryana) during 1995 and 2000 in Bioscience. She is working as a Senior Research Associate with the Biomolecular Electronics and Conducting Polymer Research Group (BECPRG) at the National Physical Laboratory, New Delhi, India. She is actively engaged in the technical development of biosensors for healthcare. 